\title{
СМИ КАК АКСИОЛОГИЧЕСКИЙ РЕГУЛЯТОР ОБЩЕСТВЕННОГО СОЗНАНИЯ: СОЦИАЛЬНО-ФИЛОСОФСКИЙ АСПЕКТ
}

\section{MASS MEDIA AS AN AXIOLOGICAL REGULATOR OF PUBLIC CONSCIOUSNESS: SOCIAL AND PHILOSOPHICAL ASPECT \\ D. Izmailova}

Summary: The article analyzes the role of modern mass media in the formation of the value content of human consciousness. As a result of the analysis of the value composition of modern mass media, a classification of mass media according to their axiological significance has been proposed. The degree of influence of modern media on the formation of value orientations and the transformation of the consciousness of youth is considered. The socio-cultural significance of the media in the formation of public consciousness has been proved.

Keywords: mass media, values, axiology, value content, object values, spiritual values.

\author{
Измайлова Джамиля Ибрагимовна \\ Старший преподаватель, ГО ВПО «Донецкий \\ национальный университет экономики и торговли \\ имени Михаила Туган-Барановского» \\ Jamilyushka@yandex.ru
}

Аннотация: В статье проанализирована роль современных средств массовой информации в формировании ценностного наполнения человеческого сознания. В результате анализа ценностного состава современных средств массовой информации предложена классификация СМИ по их аксиологической значимости. Рассмотрена степень влияния современных СМИ на формирование ценностных ориентиров и трансформацию сознания молодёжи. Доказана социокультурная значимость СМИ в процессах формирования общественного сознания.

Ключевые слова: средства массовой информации, ценности, аксиология, ценностное наполнение, предметные ценности, духовные ценности.

Методологический каркас исследования составляют определённые принципы, подходы и методы. Принцип объективности обеспечивает всесторонний и комплексный анализ предмета исследования, на основе которого проведена классификация современных российских СМИ по степени аксиологической значимости и наполненности; принцип компаративизма позволил провести сравнительный анализ влияния различных форм СМИ на сознание человека.

Исследование проводилось на основе ценностного, многомерного и междисциплинарного подходов.

Формирование ценностного наполнения человеческого сознания может быть продиктовано и обусловлено множеством социокультурных и социально-экономических явлений общественной жизни. В социологии и педагогике принято считать, что ценностные ориентиры личности формируются в период её социального становления в различных социальных группах: от детского сада до трудового коллектива и круга друзей. То есть основное ценностные ориентиры личности формируется под влиянием различных институтов социализации. Здесь необходимо отметить имеющуюся бинарность процесса социализации, т.е. не только индивид усваивает имеющийся социальный опыт и аксиологические ориентиры данной группы, но и социальная группа способна трансформироваться под воздействием опыта индивида. Исходя из этого очевидно, что формирование ценностного наполнения личности может происходить как за счёт 
уподобления значимым персоналиям социальной группы (общества), так и за счёт присвоения общественных ценностей [1, с 12].

В контексте данного исследования мы будем рассматривать степень влияния средств массовой информации на формирование ценностных ориентиров и трансформацию общественного сознания. Здесь автор считает необходимым задаться рамками концептуализации понятия ценности. В данном случае, имеет смысл разделить ценности на базовые группы:

- предметные ценности. К ним отнесём все ценности материальной культуры человечества, имеющие положительную значимость;

- духовные ценности. К ним отнесём оценочные стороны всех явлений общественной жизни, а именно: общественные установки, нормы морали, представления о смысле жизни, добре, справедливости и т.д.

В рамках данного исследования проанализируем влияние СМИ на формирование духовных ценностей.

Предшественниками нынешних средств массовой информации стоит считать так называемые куранты, появившиеся в Российской империи еще при Петре I и представлявшие собой рукописные обзоры немецкой и голландской прессы. В 1720 году появились печатные «Санкт-Петербургские ведомости», а в 1756 году «Московские ведомости». К 1917 году пресса Российской империи стала одной из мощнейших на то время в мире - различная периодика выходила без малого в 200 городах России.

Традиционно принято выделять четыре этапа в развитии средств массовой информации:

1-ый этап - эпоха газет. Для этого этапа характерно активное использование СМИ властью для целенаправленного воздействия на граждан. С помощью газетных сообщений формировалось общественное мнение.

2-ой этап - радиоэпоха. Начинается примерно с 1921 года, когда в России началось регулярное массовое проводное вещание, и продолжается вплоть до 40-ых годов XX столетия. Очевидно, что эффективность информационного влияния вышла на новый уровень, т.к. благодаря радиотехнологиям спектр информационного воздействия расширился от новостных газетных сообщений до информационно-развлекательных и познавательных программ. Кроме того, очевидно, что расширился круг объектов воздействия: газеты были доступны только грамотной части граждан, а радиосообщения могли слушать на улице все желающие.

3-ий этап - эпоха телевидения. Хронологически это наиболее длительный и максимально эффективный этап эволюции СМИ. Его продолжительность порядка 50 лет, вплоть до появления глобальной сети. Эффективность информационного воздействия на граждан объясняется синхронным воздействием на основные органы чувств человека - зрительный и слуховой $[2$, с.4].

По мнению автора из перечисленных выше средств вещания, особое место занимают печатные СМИ. Это объясняется тем, что содержание информации, выраженной в письменной форме более склонно к аналитичности. То есть сам процесс чтения предполагает активную интеллектуальную работу по усвоению, интерпретации и анализу полученной информации. Кроме того, к печатной информации всегда можно вернуться для уточнения, детализации, переосмысления и т.д.

При этом основные преимущества радио связаны с оперативностью, абсолютной доступностью и технической простотой и дешевизной производственного процесса. Стоит отметить, что выразительные средства радиожурналистики - прямые эфиры, живой голос и т.д. обладают достаточно высоким потенциалом в реализации поставленных задач по формированию общественного мнения.

И наконец, телевидение. Оно органично сочетает в себе возможности радио, кино, живописи, театра и т.д., тем самым добиваясь полного жизнеподобия транслируемых картин. Причинами столь быстрого распространения телевидения можно назвать, в первую очередь, зрелищность - известный факт, что 90\% информации об окружающем мире человек получает именно через зрительный анализатор. Ну, а кроме того, для восприятия телевидения не требуется никаких специальных знаний или навыков, даже элементарной грамотности.

Наиболее важным и интересным этапом в развитии СМИ можно считать четвёртый этап.

Четвертый этап - эпоха глобализации - время, когда на массовое сознание воздействуют все предыдущие СМИ (газеты + радио + телевидение) и появляется глобальная сеть Интернет [2, с. 5]. Мы предлагаем этот этап считать началом качественно нового уровня: переход средств массовой информации в средства массовой коммуникации, поскольку любой пользователь сети может не только знакомится с новостями в Интернете, но и предлагать своё альтернативное видение существующей информации.

Анализируя этапы эволюции СМИ, становится очевидным, что кроме своей основной функциональной нагрузки (информационной, просветительской, развлекательной и т.п.) СМИ всегда были не только идейными вдохновителями, идеологическим локомотивом, но аксиологическим ретранслятором любого общества.

Определим назначение и основные функции СМИ в 
Российском обществе.

Согласно ряду исследований [3, с.140], выделяют четыре основные теории для характеристики СМИ.

1. Авторитарная теория. Согласно этой теории, СМИ предназначены для поддержания и проведения политики действующего правительства и обслуживания государственных интересов.

2. Либертарианская теория. Согласно этой теории основная цель СМИ заключается в информировании и развлечении общества, но при этом в помощи в определении истины и контроле правительственных действий.

3. Теория социальной ответственности. Основные цели СМИ по этой теории заключаются в информировании и развлечении, но при этом в переводе возможных социальных конфликтов на уровень обсуждения.

4. Советская социалистическая теория. Согласно этой теории, основная цель СМИ - способствование успеху и поддержанию советской социалистической власти, а в частности диктатуры партии.

На сегодняшний день в современной России сформировался подход к средствам массовой информации близкий к либертарианской теории. Этот подход также называют «концепцией свободной воли» [4, с. 21]. Согласно этой концепции главной целью современных СМИ является удовлетворение потребности общества в информации.

Расширение масштабов использования средств массовой коммуникации в XXI в. актуализировало общественное сознание как продукт коммуникативноинформационных технологий. На сегодняшний день масс-медиа можно смело назвать мощнейшим средством воздействия на ценностные ориентиры общества, его моральные и нравственные установки. Как указывает Городенко Л.М., важнейшей функцией и основным назначением современных масс-медиа является предоставление конечному потребителю объективной информации и реальной картины настоящего, обеспечение свободы мысли и слова, а также предоставление права публично выражать свои мысли и отстаивать гражданскую позицию [2, с. 9]. В свою очередь Г.Г. Почепцов указывает, что СМИ должны осуществлять контроль за работой различных ветвей власти, поднимать актуальные вопросы и следить за ходом их решения, выполнять роль общественного наблюдателя, представлять интересы конечного потребителя общественной информации [3, с.143]. По мнению автора в условиях глобализационных тенденций ведущая роль СМИ в формировании гражданского сознания заключается не только в самом определении СМИ как «четвёртой власти», т.е. в выполнении функции не столько идеологического и политического влияния, сколько социокультурного влияния и воспитания. Т.е. в нашем понимании помимо основных общепринятых функций СМИ на первый план сегодня выходит функция аксиологическая. В контексте современных глобальных кризисов ключевой вектор движения российских (и не только) СМИ ориентирован, в первую очередь, на массовое потребление и коммерческий успех; традиционные культурные ценности заменены на псевдоценности и мнимые (часто генетически чуждые) аксиологические установки. Следствием такого развития СМИ вполне обоснованно стали очевидные сдвиги в традиционной иерархии ценностных компонентов в сторону этических «суррогатов».

«Аксиосфера» современных СМИ не имеет единого социокультурного стержня. Это обусловлено, в первую очередь, тем, что современное мировое сообщество по своей сути сегодня является поликультурным. Поэтому из всех доступных средств массовой информации к нам каждодневно доносят христианские (мусульманские, буддийские и т.д.) или демократические (республиканские, монархические и т.д.) и иные ценностные категории, при этом однозначным мерилом данных ценностей (или псевдоценностей) не может, пожалуй, выступить никто.

Изучить ценностный состав современных медиа представляется довольно сложной задачей по многим причинам. В рамках настоящего исследования автор предлагает ввести некую условную классификацию СМИ по степени аксиологической значимости и наполненности. При составлении данной классификации автор опирается на базовую систему ценностей.

1. Религиозные СМИ. Данную категорию СМИ автор выносит на первое место в силу того, что именно религиозные СМИ могут и способны сформировать у гражданина базовые ценности для данного общества. В нашем случае такими СМИ могут выступить православные печатные издания, теле- и радиоканалы, христианские сайты и интернет сообщества. Хотя в России, так исторически сложилось, и представлены все мировые религии, но общие точки соприкосновения в фундаментальных ценностях есть.

2. Культурно-просветительские СМИ. Сюда отнесём периодические издания, телепроекты и сайты, посвящённые литературе и искусству, научно-популярные и просветительские программы.

3. Патриотические СМИ. К этой категории отнесём многочисленные сетевые проекты патриотической направленности, радиостанции и телеканалы (например, «Звезда»), периодические издания.

4. Научные СМИ. К этой категории отнесём специализированные СМИ строго научной направленности, способные формировать правильную картину мира. 
Анализ рейтингов современных СМИ показал, что подавляющее большинство из них находится в некоем «ценностном хаосе». Например, к программам с наибольшим рейтингом за 2018 и 2019 год относятся токшоу «Пусть говорят», «Прямой эфир», «Давай поженимся», «Секрет на миллион», а также ряд телесериалов. Необходимо отметить, что самой рейтинговой программой 1-го канала Российского телевидения за 2019 год стала трансляция парада Победы.

Значительно раньше анализируемого рейтинга, а именно в июне 2005 года была принята «Хартия телевещателей против насилия и жестокости», подписанная руководителями шести российских телеканалов. В частности в указанном документе говорится, что все без исключения должны принять всевозможные меры к недопущению нанесения ущерба общественной нравственности $[5,6]$.

Процесс формирования социокультурных ценностных ориентиров средствами массовой информации можно условно разделить на три этапа.

Первый этап - синтез определенной ценности на основе наблюдения за отдельными фактами общественной жизни и показа этих фактов.
Второй этап - популяризация данной ценности или включение её в систему уже существующих в данном обществе ценностей.

Третий этап - утверждение данной ценности в системе путём её пропаганды в обществе [7, с.913].

Очевидно, что на первом и втором этапе формирования ценности ключевую роль играют именно средства массовых коммуникаций. А третий этап, что называется, дело техники при условии чётко отработанных первых двух.

Выводы. Исходя из вышеизложенного, становится очевидным, что современные средства массовой информации являются одним из самых мощных средств, ответственных за формирование ценностных ориентиров, моделей поведения и стереотипов мышления в современном социуме. Этот факт констатирует необходимость признания значимости СМИ в процессах формирования и трансформации ценностных основ внутреннего мира человека, в формировании духовно-нравственных основ личности.

Перспективой дальнейших исследований является анализ воздействия СМИ на сознание молодёжи в контексте влияния социальных сетей на формирование духовно-нравственных ориентиров.

ЛИТЕРАТУРА

1. Погорелая Л.П. Негосударственные средства массовой информации как институт гражданского общества (теоретико-правовой аспект): Автореф. дис. ... канд. юрид. наук. - Киев, 2015. - 20 с.

2. Городенко Л.М. Средства массовой информации в контексте общественного мнения: формирование, функционирование, жанровые приёмы: Автореф. дис. ... канд. филол. наук. - Киев: 2003. - 12 с

3. Почепцов Г.Г. Информационно-политические технологии. М.: Центр, 2003. - 381 с.

4. Чубенко Д.С. Ценности современной России // Сборник научных статей. - Нижний Новгород: Изд. НГУ, 2006. С. 21.

5. Баркова Э.В. Планетарный смысл сохранения гуманитарно-интеллектуального потенциала культуры: взгляд экофилософа // Культурно-языковое взаимодействие в процессе преподавания дисциплин культурологического и лингвистического циклов в современном полиэтничном ВУЗе. Материалы IV Всероссийской (с международным участием) научно-методической конференции. Под редакцией Л.Д. Торосян. - М.: 2018. С. 23-31.

6. Баркова Э.В. Гуманитарное мышление в экофилософских ориентирах самоидентификации субъекта современного мира // Право и практика. 2018 . № 1. C. 248-255.

7. Волков, В.А. Влияние СМИ на формирование культурных ценностей: аксиологический аспект // Молодой ученый. — 2015. — № 3 (83). — С. $913-915$. — URL: https://moluch.ru/archive/83/15136/ (дата обращения: 31.05.2021).

(с) Измайлова Джамиля Ибрагимовна (Jamilyushka@yandex.ru). 